\title{
Contents, Vol. 24, 1985
}

Founded 1897 as 'Monatsschrift für Psychiatric und Neurologic', continued 1957-1967 as “Psychiatria et Neurologia’'Founders: C. Wernicke and Th. Ziehen. Successors: K. Bonhoeffer (1912-1938), J. Klaęsi (1939-1967), E. Grunthal (1953-1967)

\section{Editor-in-Chief \\ Editorial Board}

Advisory Board

H.E. Kaeser, Basel

L. Barraquer Boardas, Barcelona

Electromyography

S. Feldman, Jerusalem

H.P. Ludin, Bern

Associate Editor

P. Hubcr, Bern

Neuroendocrinology

C. Loeb, Gcnova

A. Kreindler, Bucharest

H.-G. Mertens, Wiir|.burg

H.J. Lehmann, Essen

P.O. Lundberg, Uppsala

U.K. Rinne, Turk

C. Pallis, London

Cerebrospinal Fluid

H. vander Eecken, Ghent Satoyoshi, Tokyo
E.

H.B. Rieder, Basel

F. Scitelberger, Vienna J. Ulrich, Basel F. Vasella, Bern

Electroencephalography

G. Scollo-Lavi//zari, Bas

Evoked Potentials

W. Tackmann, Bonn

Ophthalmo-Neurology O. Mciênberg, Basel

$\mathrm{S}$. Karger $\bullet$ Medical and Scientific Publishers

Basel $\bullet$ Miinchen $\bullet$ Paris $\bullet$ London $\bullet$ New York $\bullet$ New Delhi $\bullet$ Singapore $\bullet$ Tokyo $\bullet$ Sydney

Drug Dosage

The authors and the publisher have exerted every effort to ensure that drug selection and dosage set forth in this text are in accord with current recommendations and practice at the time of publication. However, in view of ongoing research, changes in government regulations, and the constant flow of information relating to drug therapy and drug reactions, the reader is urged to check the package insert for each drug for any change in indications and dosage and for added warnings an precautions. This is particularly important when the recommended agent is a new and/or infrequently employed drug

All rights reserved. without permission in writing from the publisher or, in the case of photocopying, direct payment of a specified fee to the Copyright Clearance Center (see 'Information for Readers and Subscribers').

(c) Copyright 1985 by

\section{Contents Vol. 24,1985}


A Multinational Comparison of Drug Treatment in Patients with Cerebrovascular Disease

Spagnoli, A.; Tognoni, G.; Darmansjah, I.; Laporte, J.-R.; Vrhovac, B.; Treacher, D.F.;

Warlow, C.P.

Posttraumatic Neuroma of the Median Nerve: A Cause of Carpal Tunnel Syndrome

Martinelli, P.; Poppi, M.; Gaist, G.; Padovani, R.; Pozzati, E.

Pattern of Albumin, Immunoglobulins, and Glucose in Cerebrospinal Fluid and Serum of

Patients with Disorders of the Central Nervous System

Osenbriick, M.; Rao, M.L.; Quednau, H.D ......................................................................... 16

Effect of Large Doses of Methylprednisolone on Supratentorial Intracranial Tumors. A Clinical and CAT Scan Evaluation

Leiguarda, R.; Sierra, J.; Pardal, G; Zambrano, D ............................................................................. 23

Chronotographical Potential Distribution of Some SSEP Components in Cerebrovascular

Insufficiency

Colon, E.J.; Leeuw, H. v.d.; Thijssen, H.O.M.; Boumen-v.d. Eerden, R.; Dirven, C. . 33 Quantitation of Multiple Sclerosis Specific Central Nervous System Antigens in Various Regions of MS Brains

Rastogi, S.C.; Clausen, J.; Tourtellotte, W.W ...

Endothelial Mitochondrial Content of Cerebral Cortical Capillaries in Alzheimer's Disease.

An Ultrastructural Quantitative Study

Mancardi, G.L.; Tabaton, M.; Liwnicz, B.H 41

Use of Testosterone in the Treatment of Cluster Headache

Klimek, A

Bilateral Obstruction of Internal Carotid Artery from Giant-Cell Arteritis and Massive

Infarction Limited to the Vertebrobasilar Area

Bogousslavsky, J.; Deruaz, J.P.; Regli, F .

Matsunoto, A.; Watanabe, K.; Sugiura, M.; Negoro, T.; Takaesu, E.; Iwase, K

Acute Peroneal Compartmental Syndrome. Report of a Case

Arancio, O.; Bongiovanni, L.G.; De Grandis, D

Preventive Treatment of Cerebral Transient Ischemia: Comparative Randomized Trial of

Pentoxifylline versus Conventional Antiaggregants

Herskovits, E.; Famulari, A.; Tamaroff, L.; Gonzalez, A.M.; Vazquez, A.; Dominguez, R.;

Fraiman, H.; Vila, J

The Myxomatous Mitral Valve. A Risk Factor for Ischemic Stroke in Young Patients?

Zenker, G.; Bone, G.; Ladurner, G.; Lechner, H.

Contents

No. 2 Atypical Phenotype of Refsum's Disease: Clinical, Biochemical, Neurophysiological and Pathological Study

Dotti, M.T.; Rossi, A.; Rizzuto, N.; Hayek, G.; Bardelli, N.; Bardelli, A.M.; Federico, A. 85 Myelopathy as the Main Presenting Feature of Systemic Lupus erythematosus

Al-Husaini, A.; Jamal, G.A ………................................................................................................ 94

Chronic 'Locked-In' Syndrome: Psychological Study of a Case

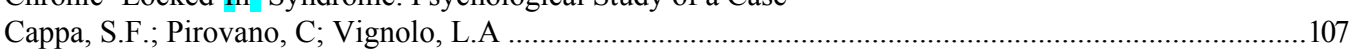

Facial Myokymia - A False Localizing Sign in Obstructive Communicating Hydrocephalus.

A Case Report

Sandyk, R

Amyotrophic Lateral Sclerosis Presenting with Respiratory Insufficiency as the Primary

Complaint. Clinicopathological Study of a Case

Meyrignac, C; Poirier, J.; Degot, J.D

Hypercalcemic Encephalopathy in the Course of Hyperthyroidism

Juvarra, G.; Bettoni, L.; Olivieri, M.F.; Bortone, E.; Cavatorta, A.................................................................121

Local Immunoglobulin Synthesis and Blood-Brain Barrier Assessment in Subacute Sclerosing Panencephalitis

Silva, C.A.; Rio, M.E.; Cruz, C

Prognostic Value of Computed Tomography in Aphasic Stroke Patients

Demeurisse, G.; Capon, A.; Verhas, M ...

Asymptomatic Large Arachnoid Cyst of the Middle Cranial Fossa. A Clinical and Neuropsychological Study

Gallassi, R.; Ciardulli, C; Ferrara, R.; Lorusso, S.; Galassi, E.; Lugaresi, E ............................................... 140

No. 3 Spontaneous Cerebellar Hemorrhage after Coronary Artery Bypass Surgery

Anderson, D.E.; Biller, J.; Schreiber, R.R

Subacute Sclerosing Panencephalitis and Hypoparathyroidism

Cianchetti, C; De Virgiliis, S.; Marrosu, M.G. Loi, M............

Refsum's Disease: Management by Diet and Plasmapheresis

Hungerbiihler, J.P.; Meier, C; Rouselle, L.; Quadri, P.; Bogousslavsky, J.................................................. 153

Acute Ascending Motor Paralysis due to Rabies: A Clinicopathological Report

Classic Migraine - Clinical Findings in 164 Patients

Manzoni, G.C.; Farina, S.; Lanfranchi, M.; Solari, A ...

Multicore Disease and Marfan's Syndrome: A Case Report

Pages, M.; Echenne, B.; Pages, A.-M.; Dimeglio, A.; Sires, A

Regional Cerebral Blood Flow in Schizophrenic Disorders

Kurachi, M.; Kobayashi, K.; Matsubara, R.; Hiramatsu, H.; Yamaguchi, N.; Matsuda,

07

12

.

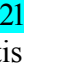
. . 
Adaptation of Hepatic Ammonia Metabolism after Chronic Valproate Administration in

Epileptics Treated with Phenytoin

Marescaux, C; Waiter, J.M.; Brandt, C; Rumbach, L.; Micheletti, G.; Chabrier, G.;

Imler, $\mathrm{M}$

Monitoring of Antifibrinolytic Treatment in Subarachnoid Hemorrhage

Hossmann, V.; Bewermeyer, H.; Auel, H.; Heiss, W.-D ..............

Jain, S.; Maheshwari, M.C.; Dhamija, R.M.; Mishra, N.K.

Contents

$\mathrm{V}$

Case of Dementia and Myoclonia in an Adult Associated with Anomalies in Polyunsaturated Fatty Acids in Leukocytes and Peripheral Nerve. An Ultrastructural Study of Peripheral Nerve Vallat, J.M.; Bourre, J.M.; Dumont, O.; Leboutet, M.J.; Loubet, A.; Corvisier, N.;

Dumas, $\mathrm{M}$ 208

No. 4 PontomeduUary Encephalitis and Basal Meningitis due to Listeria monocytogenes: Report of a Case

Callea, L.; Donati, E.; Faggi, L.; Scalzini, A.; Callea, F

Acute Brain Edema due to Water Loading in a Young Woman

Kott, E.; Marcus, Y

Therapy Be Used?

Booss, J.; Haak, B.B.; Leroy, R.F .......................................... 225

Morphological Studies of Peripheral Nerves and Skeletal Muscles of an Adult Case with

Adrenoleukomyeloneuropathy

Kumamoto, T.; Fukuhara, N.; Ohno, T.; Wakabayashi, M.; Miyatake, T.................................................... 229

Subclinical Effects of Exposure to Inorganic Mercury Revealed by Somatosensory-Evoked

Potentials

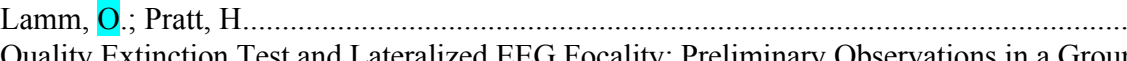

Quality Extinction

of Epileptic Patients

Scarone, S.; Gambini, O.; Pieri, E.; Canger, R

Case Report

Lang, C....

Does Acute Endoscopic Evacuation Improve the Outcome of Patients with Spontaneous

Intracerebral Hemorrhage?

Auer, L.M.; Ascher, P.W.; Heppner, F.; Ladurner, G.; Bone, G.; Lechner, H.; Tolly, E. 254 Effects of Intravenously Administered L-Acetylcarnitine on Somatosensory-Evoked Potentials. Studies of Healthy and Diseased Volunteers with Focal Cerebral Lesions

Rossini, P.M.; Di Stefano, E.; Febbo, A.; Gambi, D.; Calvani, M .............................................................262

Percutaneous Radio Frequency Gangliolysis in the Treatment of Trigeminal Neuralgia

Lahuerta, J.; Lipton, S.; Miles, J....

Occipital Infarctions Associated with Hemiparesis

Short-Term Outcome of Medically Treated Patients with Transient Ischemic Attacks,

Reversible Ischemic Neurologic Deficits and Strokes with Minimum Residuum

Calandre, L.; Molina, J.A.

Successful Treatment of Neuroleptic-Induced Akathisia with Baclofen and Clonazepam. A

Sandyk, R......

No. 5 Isolated Complete Paralysis of the Tensor fasciae latae Muscle

Muller-Vahl, $\mathrm{H}$

Nitrous Oxide Ameliorates Spasmodic Torticollis

Gillman, M.A.; Sandyk, R.

Long-Term Study of Isoprinosine in a Case of Subacute Sclerosing Panencephalitis De Reuck, J.L.; Boon, P.A.; Krahel, N.L.................................................................... 294

Oligoclonal IgG Bands in the CSF of a Patient with Progressive Familial Myoclonus

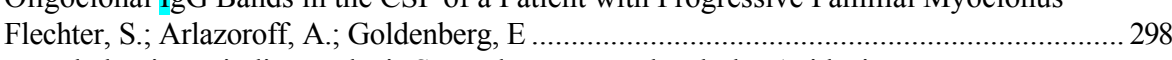

Hypokalemic Periodic Paralysis Secondary to Renal Tubular Aci.............

Christensen, K.S.

Successful Pregnancy in Wilson's Disease: A Case Report and Review of the Literature

Biller, J. Swiontoniowski, M. Brazis, P.W ...

Peripheral Neuropathy in Meningococcal Septicemia

Roig, M.; Santamaria, J.; Fernandez, E.; Colomer, J .

Fisher's Syndrome following Trigeminal Herpes zoster 
Uematsu, D. Satoh, T.: Tanahashi, N.; Koto, A.; Gotoh, F

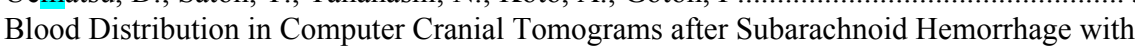

and without an Aneurysm on Angiography

Stober, T.; Emde, H.; Anstatt, T.; Freier, G.; Metzger, U ..................................................... 319

Pattern Visual Evoked Potentials and Flash Electroretinogram in Clinically Definite Multiple Sclerosis

Pierelli, F.; Pozzessere, G.; Stefano, E.; Martelli, M.; Rizzo, P.A.; Morocutti, C .................... 324

Treatment of Orthostatic Hypotension in Shy-Drager Syndrome with DL-Threo-3,4-dihy-

droxyphenylserine: A Case Report

Sakoda, S.; Suzuki, T.; Higa, S.; Ueji, M.; Kishimoto, S.; Matsumoto, M.; Yoneda, S.. 330 Efficacy of Trazodone in Narcolepsy

Sandyk, R .............................................................................................................. 335

Cerebellar Infarction - Clinical and Cranial Computerized Tomography Correlations

Swiontoniowski, M.; Biller, J.; Azar-Kia, B.; Fine, M..

Effects of GM| Ganglioside in Cerebrovascular Diseases: A Double-Blind Trial in 40

Cases

Cases

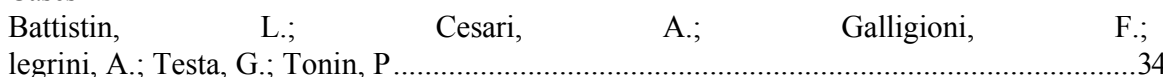

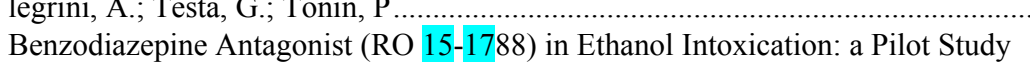

Scollo-Lavizzari, G.; Matthis, H.

Versive Seizures of Probable Occipital Origin in a Case of Posttraumatic Epilepsy

L. Oiler, F.-V.; Fossas, P.; Sanchez, M.E.; Russi, A ......................................................... 355

Announcement...

A Study of Some Immunological Variables in Twins, Discordant for Multiple Sclerosis Heltberg, A.; Kalland, T.; Kallen, B.; Nilsson, 0

Effects of Lisuride on Blink Reflex Habituation in Parkinson Disease

Sandrini, G.; Alfonsi, E.; Martignoni, E.; Horowski, R.; Nappi, G ............................................374

Baclofen as an Anatgesic in Chronic Peripheral Nerve Disease

(a)

Baclofen as an Analgesic in Chronic Perip

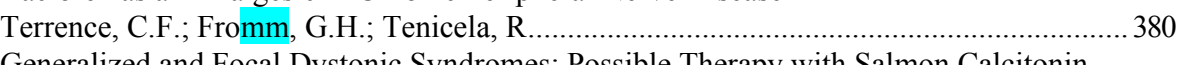

Generalized and Focal Dystonic Syndromes: Possible Therapy with Salmon Calcitonin

Patti, F.; Marano, P.; Nicoletti, F.; Giammona, G.; Nicoletti, F...

Brain Metabolism in Deep Controlled Hypotension in Neurosurgical Patients

Ryba, M.; Johansson, K.; Cybulska, A...

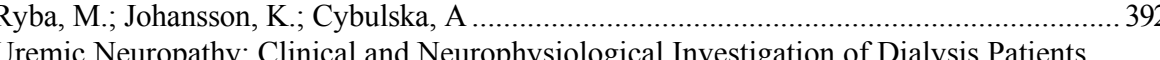

Using Different Chemical Membranes

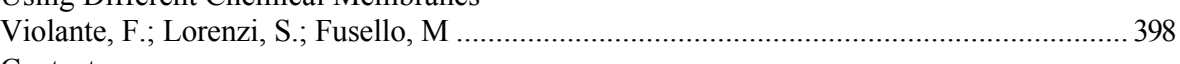

Contents

VII

Sensory Signs and Symptoms in Scapuloperoneal Atrophy: A Report of a Family

Sand, T.; Hestnes, A

.405

An Approach Using Lecithin Treatment for Olivopontocerebellar Atrophies

Finocchiaro, G.; Di Donato, S.; Madonna, M.; Fusi, R.; Ladinsky, H.; Consolo, S. . . 414 Neurology and the Lupus Anticoagulant

Englert, H.; Derue, G.; Hughes, G.R.V 422

Platelet Behavior in Patients with TIA: Responsiveness to Small Doses of Aspirin

D’Andrea, G.; Tolldo, M.; Cananzi, A.; Cortelazzo, S.; Ferro-Milone, F .

\section{International MS Conference: Scientific Symposium}

Immunotherapy of Multiple Sclerosis - Current Status and Future Perspectives

September 15, 1984, University of Zurich, Switzerland

Author Index. 442

Subject Index. .445 